Crop Breeding and Applied Biotechnology 13: 178-185 2013

Brazilian Society of Plant Breeding. Printed in Brazil

ARTICLE

\title{
Evaluation efficiency of severity of angular leaf spot in common bean based on diseased and healthy leaf area
}

\author{
Rafael Augusto da Costa Parrella ${ }^{1}$, João Bosco dos Santos ${ }^{2 *}$, Nádia Nardely Lacerda Durães Parrella ${ }^{3}$ and Diego Velásquez \\ Faleiro e Silva ${ }^{4}$
}

Received 04 September 2012

Accepted 06 September 2013

\begin{abstract}
This study compared severity of angular leaf spot in common bean lines, based on the healthy and diseased leaf area, and the graded scale. We used 12 common bean lines in the dry and rainy seasons. Two contiguous experiments were conducted in each season, with and without chemical control of the pathogen. We evaluated the percentage of the healthy and diseased leaf area; severity based on a graded scale and the area under the disease progress curve; and yield. The diseased or healthy leaf area is efficient to evaluate the severity of angular leaf spot with a sample of 20 to 30 leaflets per plot. For all traits, the results of central and border areas did not differ, indicating that the evaluation of border rows is unnecessary and, finally, the severity assessment of the upper plant half can discriminate the lines more efficiently.
\end{abstract}

Key words: Phaseolus vulgaris, Pseudocercospora griseola, healthy and diseased leaf area, graded scale, severity.

\section{INTRODUCTION}

Common bean (Phaseolus vulgaris L.) is one of the most important constituents of the diet of Brazilian people, mainly because of its tradition and nutritional qualities (Borém and Carneiro 2006, Silva et al. 2012). Due to its relevance, the crop is grown almost year-round; this however favors the development of a number of diseases, particularly of angular leaf spot caused by the fungus Pseudocercospora griseola (Sacc.) Crous \& U. Braun. Angular leaf spot occurs in almost the whole country, all year long, especially at milder temperatures, between $16^{\circ} \mathrm{C}$ and $28^{\circ} \mathrm{C}$ (Paula Jr and Zambolim 2006). Under disease-favorable conditions, it can cause significant losses (Sartorato and Rava 1992, Paula Jr and Zambolim 2006, Borel et al. 2011).

In breeding programs for selection of resistant genotypes, the main form of assessment of the severity of angular leaf spot is by means of a graded scale, with scores ranging from 1 to 9 , based on visual ratings (Godoy et al. 1997). This kind of evaluation is subjective and depends on the experience of the evaluator. Often, the score evaluation is little correlated with grain yield (Bergamin Filho et al. 1995, Jesus Júnior et al. 2003, Couto et al. 2005), which complicates the decision-making in breeding programs for resistant and high-yielding cultivars. The lack of correlation between score evaluation and grain yield is due to the lifetime and absorption of the healthy leaf area of the host rather than of the diseased area, on which the graded scales are based (Bergamin Filho et al. 1995).

Given the disappointing results of yield damage assessment by score ratings, several authors related yield with the leaf area index (LAI), leaf area duration (LAD) and leaf area absorption (LAA) (Waggoner and Berger 1987, Bergamim Filho et al. 1997, Canteri et al. 1998). All results showed a high relationship between LAD and LAA with grain yield and no relation between score evaluation and area under the disease progress curve (AUDPC) with yield.

The use of these procedures (LAI, LAD and LAA) in breeding programs is unfeasible because the establishment of the estimates is highly labor-intensive when the number of evaluated treatments is high. An alternative would be to sample a number of leaflets and perform image analysis, to determine the healthy and diseased leaf areas. For this purpose, new characteristics that quantify the damage more accurately and that are related with grain yield must be identified.

\footnotetext{
${ }^{1}$ Embrapa Milho e Sorgo, Rodovia MG 424, km 65, C.P. 151, 35.701-970, Sete Lagoas, MG, Brazil

${ }^{2}$ Universidade Federal de Lavras, Campus Universitário, C.P. 3037, Lavras, MG, Brazil. *E-mail: jbsantos@ufla.br

${ }^{3}$ Epamig, Rodovia MG 424, km 60, 35.715-000, Prudente de Morais, MG, Brazil

${ }^{4}$ Syngenta Seeds, BR 452, 38.402-343, Uberlândia, MG, Brazil
} 
Therefore, the objectives of this study were to compare the severity of angular leaf spot in common bean lines, of estimates based on the percentage of healthy or diseased leaf area determined by digital image analysis with estimates based on the graded scale; to identify the ideal minimum number of sampled leaves to estimate the percentage of the healthy and diseased leaf areas; to verify the existence of differences in severity between leaflets collected from the top and bottom of the plant; and to compare the disease severity in the central and border area of the plots.

\section{MATERIAL AND METHODS}

The experiments were conducted in an area with no-tillage common bean and in succession to maize in the dry season 2006 and rainy season 2006/2007 in the experimental area of the Department of Biology, Federal University of Lavras, MG. This area had been used for no-tillage cultivation for about 10 years with annual maize-common bean rotation and the soil was classified as oxisol, cerrado vegetation. In all seasons, we planted a border row of cultivar Carioca MG, susceptible to Pseudocercospora griseola, circling the experiment without chemical control of the pathogen, 15 days before sowing. The entire experiment was inoculated 30 days after sowing using infected, dried and fragmented leaflets of previous harvests. In all experiments, the treatments consisted of 12 lines: Carioca-MG, BRSMG Talismã, ESAL 686, LH-11, OP-NS-331, MA-I-2-5, MA-I-18-13, CV-46 and CV-55, of the breeding program of the Federal University of Lavras (UFLA), Pérola and BRS Horizonte, of the breeding program of Embrapa Rice and Beans, and BRSMG Madrepérola, from the breeding program of the Federal University of Viçosa (UFV). These lines differ in their reaction to angular leaf spot. The susceptible lines were Carioca-MG, BRSMG Talismã, BRS Horizonte and LH-11; moderately resistant CV-46, and resistant MA-I-2-5, MA-I- 18-13, CV-55, OP-NS-331, Pérola and Madrepérola BRSMG. Line ESAL 686 has resistant pods and susceptible leaves (Mendonça et al. 2003, Abreu et al. 2007, Amaro et al. 2007, Borel et al. 2011, Carneiro et al. 2012).

In each season, two contiguous experiments with the same treatments were conducted. The experiment was arranged in a randomized block design with 12 treatments and 3 replications per plot with four 4-m rows, spaced 0.5 $\mathrm{m}$ apart, at a density of 15 seeds per meter. In one experiment the pathogen was not chemically controlled, in the other, preventive chemical control was applied with the commercial product Comet $^{\mathrm{O}}$ (pyraclostrobin, $250 \mathrm{G} \mathrm{L}^{-1}$ ), at a rate of $300 \mathrm{~mL} \mathrm{ha}^{-1}$, every 15 days, beginning 30 days after sowing. The fungicide was applied using a backpack sprayer with an average flow of $400 \mathrm{~L} \mathrm{ha}^{-1}$. All experiments were fertilized with $400 \mathrm{~kg} \mathrm{ha}^{-1}$ at sowing (8-28-16 N-P-K), plus $200 \mathrm{~kg} \mathrm{ha}^{-1}$ of ammonium sulfate as side dressing. The experiments were sprinkle-irrigated as needed. All other cultural practices were similar to those commonly applied to the crop in the region.

The traits: i) percentage of healthy (HLA) and diseased leaf area (DLA) were evaluated. To obtain these estimates, 240 leaflets were collected from each plot, 71 days after sowing in the dry-season experiment in 2006 and 74 days after sowing in the rainy-season experiment 2006/2007. Of the total sampled leaflets per plot, 120 were taken from the two center rows (central area) and 120 from the two lateral rows (border), from two positions (60 leaves from the upper half and 60 leaves from the lower half of the plant). The leaflets were photographed 10 by 10 , with an Oregon Scientific DS8333 digital camera with 3.2 megapixel. Subsequently, the images were analyzed using software Quant. 1.0 (Valle et al. 2003). The percentage (\%) of healthy and diseased area per plot was estimated, in six estimates of the upper and six of the lower plant part in the center rows, and six of the upper and six of the lower plant part in the border rows, amounting to a total of 24 values. These estimates were combined to obtain samples with different numbers of leaflets $(10,20,30,40,50$, and 60 leaves). Six different analyses of variance for each sample size were performed, except for the case of 60 leaflets, for which a single analysis was sufficient.

To estimate the ideal minimum number of leaves per sample, the linear response plateau model (LRP) and the maximum curvature of the coefficient of variation method (MCCV) were adopted. For the LRP model we used the $C V_{(X) 1}, C V_{(X) 2}$ and $C V_{(X) 3}$, for error 1, error 2 and error 3, respectively, of the analysis of variance in a split-plot in space, with the different numbers of leaflets mentioned above. Then, using the PROC NLIN procedure of software SAS (SAS 2001), the values of $\beta_{0}, \beta_{1}, P$ and $X_{0}$ of model 1.0 were estimated (Ferreira 2006, Paranaíba et al. 2009).

$$
\mathrm{CV}_{(X)}=\left\{\begin{array}{lll}
\beta_{0}+\beta_{1} X+\varepsilon_{x} & \text { if } & X \leq X_{0} \\
C V P+\varepsilon_{x} & \text { if } & X>X_{0}
\end{array}\right.
$$

where $\mathrm{CV}(\mathrm{X})$ is the coefficient of variation for the total plot size of $\mathrm{X}$; $\mathrm{X}$ is the number of grouped leaflets; $\mathrm{X}_{0}$ is the optimal number of leaflets for which the linear model is transformed into a plateau, in relation to the abscissa; CVP is the coefficient of variation at the point corresponding to the plateau (junction of the linear segment and plateau); $\beta_{0}$ and $\beta_{1}$ are the intercept and angular coefficient, respectively, of the linear segment, and $\mathrm{e}_{\mathrm{x}}$ is the error associated with the presumably normal $\mathrm{CV}_{(\mathrm{X})}$ and independently distributed with mean 0 and constant $\mathrm{s}_{\mathrm{e}}^{2}$. To fit this model, we used the least square method for nonlinear Gauss-Newton models. 
For the maximum curvature of the coefficient of variation method (MCCV), we estimated the values of the variance $\left(\mathrm{S}^{2}\right)$ and of the mean $(\overline{\mathrm{Z}})$ of the equation (Ferreira 2006, Paranaíba et al. 2009): $\hat{X}_{0}=\frac{10 \sqrt[3]{2\left(1-\rho^{2}\right) S^{2} \bar{Z}}}{\bar{Z}}$; where $\hat{X}_{0}$ represents the minimum optimal number of basic sampling units; $\left(\mathrm{S}^{2}\right)$ sample variance; $(\overline{\mathrm{Z}})$, sample mean; the calculated autocorrelation coefficient $(\hat{\rho})$ was zero $(0.30 \mathrm{~ns})$. The result of $\hat{X}_{0}$ was multiplied by $\$ 10$, which is the number of leaflets per image. By this method, it is not necessary to group the basic experimental units (BEU), consisting of the mean of 10 leaflets per image.

The severity of angular leaf spot was obtained by means of a graded scale (Godoy et al. 1997) with grades varying from 1 to 9 , evaluated three times per season $(57,64$ and 71 days after sowing in the dry season of 2006, and 60,67, and 74 days after sowing in the rainy season of 2007/2008). The AUDPC, based on the scores given to the lines in the three evaluation periods in each season, was estimated by the following equation (Campbell and Maden 1990): $A U D P C=\sum_{i=1}^{n-1}\left[\left(X_{i}+X_{i+1}\right) / 2\right]\left(t_{i+1}-t_{i}\right)$, where $\mathrm{X}_{\mathrm{i}}$ is the disease severity in season $\mathrm{i}=1,2$ and $3 ; \mathrm{X}_{\mathrm{i}+1}$ is the disease severity in season $i+1 ; t_{i}$ is the time of evaluation $i$ (number of days after sowing); $t_{i+1}$ is the evaluation time $i+1$.

The grain yield of the center area and border rows of each plot was obtained in $\mathrm{mg} / \mathrm{plot}$. Subsequently, the data were transformed to $\mathrm{kg} \cdot \mathrm{ha}^{-1}$ for standardization of analysis. The relative grain yield was also obtained in percentage, using the expression: $R P_{i}=\frac{Y N C}{Y W C} x 100$, where $R P$ is the relative yield percentage of the plot $(i=1,2, \ldots, 36), Y N C$ is the grain yield in $\mathrm{kg} / \mathrm{ha}$ of plot $\mathrm{i}$ of the experiment with no chemical control of the pathogen; $Y W C$ is grain yield in $\mathrm{kg} / \mathrm{ha}$ of plot $\mathrm{i}$ of the experiment with chemical control of the pathogen.

Firstly, analysis of variance was performed for each character per experiment. After the assumptions were accepted (Ramalho et al. 2012), combined analyses of variance were conducted for all traits in the two seasons. The softwares SAS (SAS 2001) and SISVAR (Ferreira 2011) were used for data analysis.

For the percentage of healthy and diseased leaves, analyses of variance of the experiments were conducted involving lines, central or border area and plant positions, with split plots in space (position and area), for each season, where the data per plot were based on an average of 60 leaflets. For the scores, analysis of variance was performed in each experiment involving the different evaluation times using a procedure similar to that presented by Steel et al. (1997) in a split plot in time. For grain yield, analyses of variance of experiments without chemical control of the pathogen were conducted involving central and border area, in split plots in space in each season. Thereafter, the combined analysis of variance between seasons was performed for the traits in the two seasons (Ramalho et al. 2012).

The interaction lines-by-seasons for scores was decomposed using the following estimator (Cruz and Castoldi 1991): $\sigma_{G A}^{2}=0,5\left(\sqrt{Q_{1}}-\sqrt{Q_{2}}\right)^{2}+\sqrt{(1-r)^{3} Q_{1} Q_{2}}$; where $Q_{1}$ and $Q_{2}$ : represent the mean square of lines for the trait considered in the dry season 2006 (1) and rainy season 2006/2007 (2), respectively. r: correlation coefficient of the average performance of lines in the two seasons. The Spearman correlation coefficients between trait pairs were also estimated with the trait means in each season, using software SAS (SAS 2001).

\section{RESULTS AND DISCUSSION}

In the analysis of variance for percentage of healthy and diseased leaf area, there was a significant difference $(\mathrm{p} \leq$ 0.01 ) between the seasons (Table 1). The mean percentage of the healthy and diseased leaf area, considering the whole plant, were $91 \%$ and $9 \%$, and $84 \%$ and $16 \%$, respectively, in the dry season in 2006 and the rainy season of 2006/2007. Interestingly, the disease severity in the dry season 2006 was lower. The differences between lines were also significant ( $\mathrm{p}$ $\leq 0.05$ ), showing different levels of $P$. griseola resistance. The mean percentages of healthy and diseased leaf area of the lines are listed in Table 2. The lines were classified into two groups: those with more diseased leaf area were BRSMG Talismã, MA-I-2-5-ESAL 686, Carioca-MG, BRS Horizonte and LH-11, and those with a greater healthy leaf area were Pérola, MA-I-18-13 BRSMG Madrepérola, CV46, CV-55 and OP-NS-331. Although line MA-I-2-5 had been selected as resistant in a recurrent selection program for angular leaf spot resistance, its classification as susceptible was probably due to the emergence of a virulent race.

No significant differences were observed for the source of variation for area, i.e., the averages in the two center plot rows (central area) or in the two lateral rows (borders) were statistically equal to each other (Table 1 ). None of the interactions involving area was significant, showing that the performance of the lines and positions was consistent when measured in the central or border area. This suggests that although neighboring plots can affect the amount of inoculum, this influence was insignificant, indicating that border rows are unnecessary.

The differences between the assessed plant positions were significant $(p \leq .01)$. Angular leaf spot severity was 
Table 1. Summary of combined analysis of variance between seasons for percentage of healthy (HLA) and diseased leaf area (DLA), involving center and border plot rows and two positions on the plants (upper and lower), in line evaluation in the dry 2006 and rainy seasons 2006/2007

\begin{tabular}{llll}
\hline \multirow{2}{*}{ Sources of variation } & df & MS & \\
\cline { 3 - 4 } & & HLA $(\%)$ & DLA $(\%)$ \\
\hline Block (season) & 4 & 263.2 & 263.2 \\
Season & 1 & $3041 * *$ & $3041 * *$ \\
Line & 11 & $218.8 *$ & $218.8 *$ \\
Season x line & 11 & 117.5 & 117.5 \\
Error 1 & 44 & 92.43 & 92.43 \\
Area & 1 & 20.1 & 20.1 \\
Area x season & 1 & 0.475 & 0.475 \\
Area x line & 11 & 17.48 & 17.48 \\
Area x season x line & 11 & 27.12 & 27.12 \\
Error 2 & 4 & 12.30 & 12.30 \\
Position & 1 & $1692 * *$ & $1692 * *$ \\
Position x season & 1 & $95.5 *$ & $95.5 *$ \\
Position x line & 11 & $31.04 *$ & $31.04 *$ \\
Position x area & 1 & 7.95 & 7.95 \\
Position x season x line & 11 & 26.45 & 26.45 \\
Position x season x area & 1 & 7.86 & 7.86 \\
Position x line x area & 11 & 10.7 & 10.7 \\
Position x season x line x area & 11 & 9.15 & 9.15 \\
Error 3 & 140 & 16.0 & 16.0 \\
\hline Mean & & 87.51 & 12.49 \\
CV1 (\%) & & 10.99 & 77.12 \\
CV2 (\%) & & 4.01 & 28.11 \\
CV3 (\%) & & 4.57 & 32.04 \\
\hline
\end{tabular}

*, ** - Significant by the $\mathrm{F}$ test at 5 and $1 \%$ probability, respectively.

greater in older leaflets, located at the base of the plants, compared to leaflets of the apex. The average percentage of healthy and diseased leaflets collected from the plant apex was $90 \%$ and $10 \%$, respectively, and the average percentage of healthy and diseased leaflets collected from the plant base was $85 \%$ and $15 \%$, respectively. The interactions of positions $\mathrm{x}$ seasons and positions $\mathrm{x}$ lines were also significant. However, it was found that the evaluation results of the upper plant part, in both seasons were as expected, unlike the results of the lower plant part. This may be due to the confounding effect of the disease with the senescence of the lower leaves, since these evaluations occurred at the third evaluation time, i.e., nearly at the end of the crop cycle.

The experimental precision was good for the percentage of healthy leaf area, assessed by the coefficient of variation (CV) (Table 1), with $\mathrm{CV}_{1}=10.99 \%, \mathrm{CV}_{2}=4.01 \%$ and $\mathrm{CV}_{3}$ $=4.57 \%$. For the percentage of diseased leaf area, the CVs were $\mathrm{CV}_{1}=77.12 \%, \mathrm{CV}_{2}=28.11 \%$ and $\mathrm{CV}_{3}=32.04 \%$, which, of course, have the same experimental accuracy as the $\mathrm{CV}$ of the healthy area, since they were based on the same images. The differences simply reflect the influence of the mean on the CV magnitude (Ramalho et al. 2012).
The ideal number of leaflets to obtain estimates of the percentage of the healthy and diseased leaf area estimated by LRP ranged from 32.40 to 46.91 in the dry season 2006 and from 25.37 to 34.21 in the rainy season 2006/2007. Considering the three CV's, the best fit of the data to the regression equation was with the $C V_{(X) 3}$, in both seasons $\left(\mathrm{R}^{2}>0.82\right)$. For MCCV, the number of leaflets ranged from 16.23 to 28.10 in the dry season of 2006 and 15.45 to 29.49 in the rainy season of $2006 / 2007$. It is worth mentioning that the results by both methods were consistent, although the values of the method of maximum curvature of the coefficient of variation were lower in both seasons. Thus, it appears that the optimal number of leaflets to be sampled is between 15.45 and 46.91, considering the two methods, however, it is recommended to collect 30 leaves from experiments with plots of the same size, since the $\mathrm{R}^{2}$ of this value was higher. Therefore, either method can be used to obtain the optimal plot size, in agreement with the results of Paranaíba et al. (2009).

In the combined analysis of variance between seasons for severity grades of angular leaf spot, significant differences $(p \leq 0.05)$ were found (Table 3 ). The average grade of the dry season in 2006 was 3.26 and 3.56 in the rainy season, indicating greater disease severity in the rainy season, in line with the data of healthy and diseased leaf area. This small difference, although opposite to what was expected (Paula Jr and Zambolim 2006), was a peculiar condition of the experimental conditions, since the rainy season was very intense in the summer of 2006/07 and contributed to milder temperatures. Therefore, the excess moisture and especially the milder temperatures explain the slight increase in disease severity in the rainy season.

The lines differed $(p \leq 0.01)$ in terms of pathogen reaction, in agreement with the results of healthy and diseased leaf area, since the disease severity also differed in the different evaluation seasons (Table 3 ). Increasing severity was observed during evaluations in both seasons, (mean of 2.61, 3.31 and 3.86 in the $1^{\text {st }}, 2^{\text {nd }}$ and $3^{\text {rd }}$ assessment of dry season in 2006, and of 2.19,3.69 and 4.77 in the $1^{\text {st }}$ , $2^{\text {nd }}$ and $3^{\text {rd }}$ assessment of the rainy season 2006/2007, respectively). Similar results were reported by Mendonça et al. (2003). The mean score values of angular leaf spot severity in the seasons in each line, at the three assessment times differed also $(\mathrm{p} \leq 0.01)$ (Table 2$)$. The second evaluation time was the best for discriminating lines.

Interactions involving these lines were significant $(\mathrm{p} \leq$ 0.01 ) with seasons and evaluation periods, showing that the line performance was not coincident in seasons and times. The decomposition of the interaction lines $\mathrm{x}$ seasons showed a slight predominance of the complex part, corresponding to $57.82 \%$ of the interaction, although the correlation between 
the average performance of the lines in the two seasons was high and significant (0.74). However, the most susceptible cultivars (BRSMG Talismã, BRS Horizonte, LH-11, CV-46, ESAL-686 and Carioca-MG) had higher average grades, in agreement with the area-based assessments in the mean of the two seasons.

Thus, the assessment by the score diagram was more efficient to discriminate the reaction of lines to $P$. griseola than that based on the healthy and diseased leaf areas. Moreover, the ease and flexibility of the graded scale indicates this methodology as the best to assess $P$. griseola in common bean, especially in breeding programs that evaluate large numbers of progenies. These results are in agreement with observations of Borel et al. (2011) and also of Hartung and Piepho (2006), of scores assessed by specialists.
In the literature some graded scales were developed for evaluation of $P$. griseola in common bean (Costa et al. 1990, Bergamin Filho et al. 1995, Godoy et al. 1997) that differ in terms of the percentage of area infected by the pathogen at each level or score. In this study, it was found that the amplitude of the percentage values of healthy leaf area ranged from $55.76 \%$ to $99.99 \%$ in the dry season 2006 and $63.89 \%$ to $97.79 \%$ in the rainy season of $2006 / 2007$. For the percentage of diseased leaf area, the range was $0.01 \%$ to $44.24 \%$ in the dry season of 2006 and $2.18 \%$ to $36.11 \%$ in the rainy season of 2006/2007. These ranges were similar to those indicated by the graded scales (Bergamin Filho et al. 1995, Godoy et al. 1997).

To identify the reaction of the lines to the pathogen during the disease development, the AUDPC was estimated. Significant differences between lines $(\mathrm{p} \leq 0.01)$ were observed,

Table 2. Mean values for percentage of healthy (HLA) and diseased leaf area (DLA) leaf, based on score evaluations, area under the disease progress curve (AUDPC) and grain yield obtained in the evaluation of lines in the dry season of 2006 and rainy season of 2006/2007

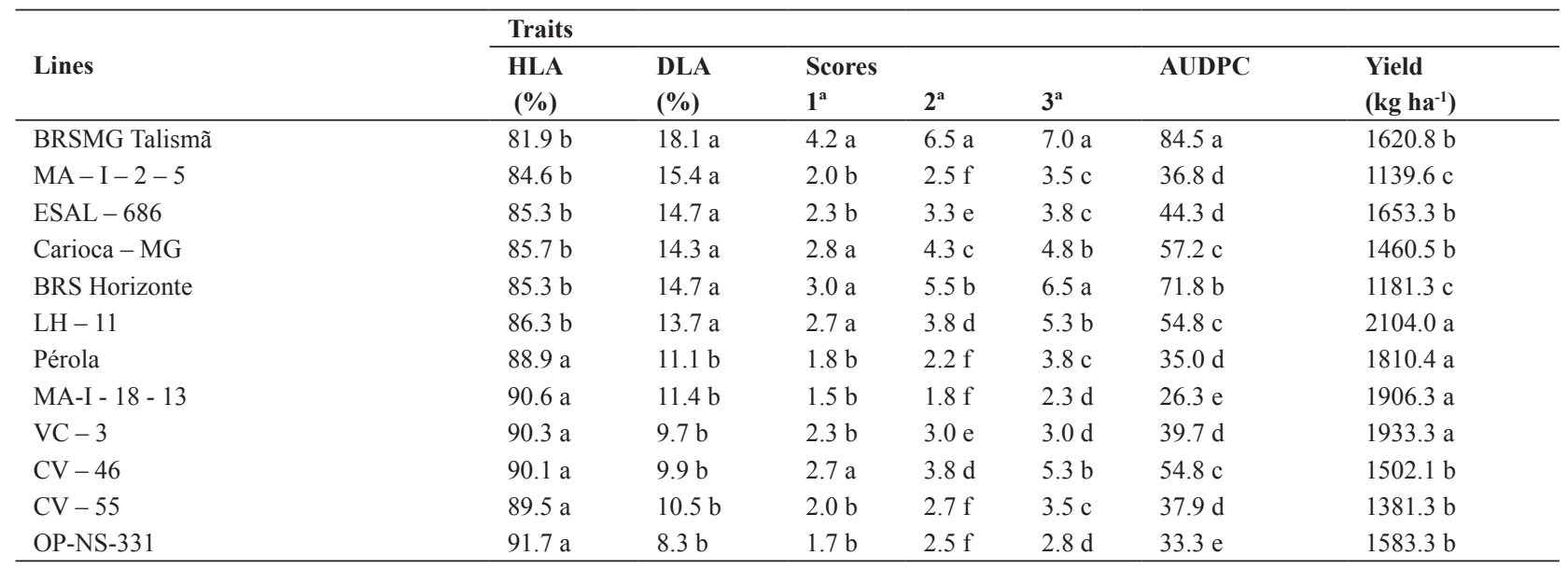

Means followed by the same letter in the same column did not differ by the Scott-Knott (1974) test at $5 \%$ probability.

Table 3. Summary of the combined analysis of variance between times of evaluation of the severity of angular leaf spot $\left(1^{\text {st }}, 2^{\text {nd }}\right.$ and $3^{\text {rd }}$ assessment - grades 1 - 9) and of grain yield $\left(\mathrm{kg} \mathrm{ha}^{-1}\right)$ of the common bean lines evaluated in the center and border plot rows in the seasons dry/2006 and rainy $2006 / 2007$

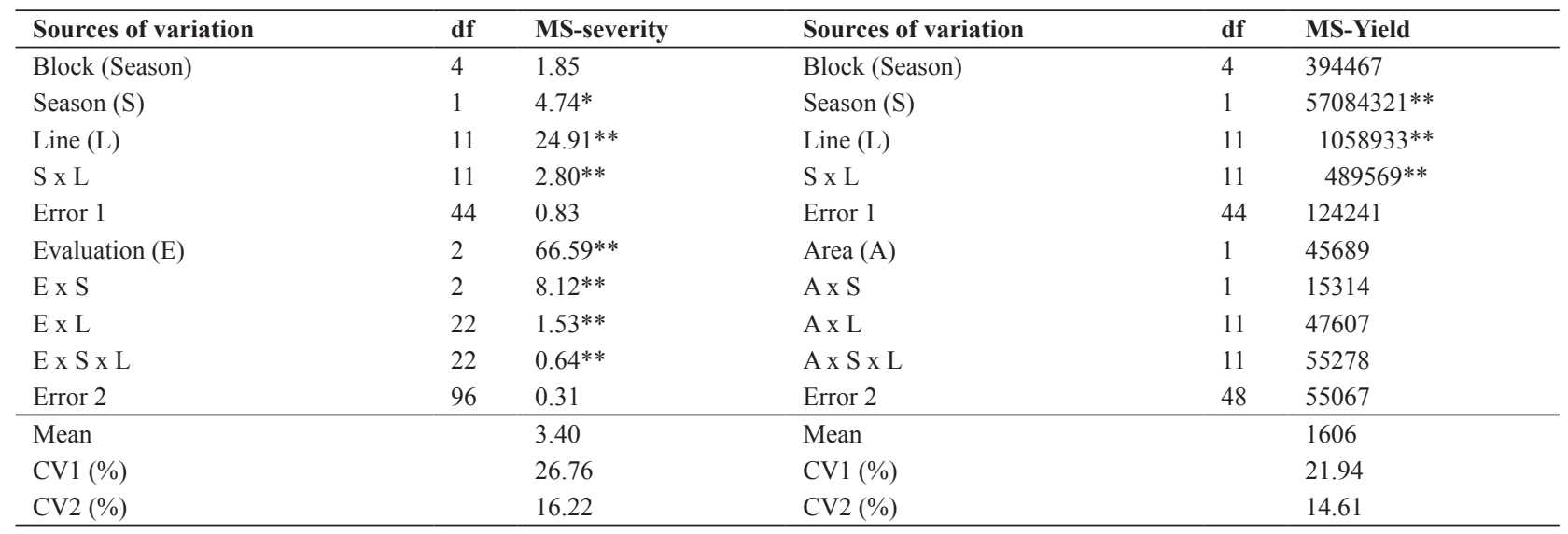

*** - Significant by the $\mathrm{F}$ test at 5 and $1 \%$ probability, respectively. 
confirming the differences in pathogen response. Interactions with seasons involving these lines were significant ( $p$ $\leq 0.01$ ), showing again that the line performance was not coincident in the evaluated seasons.

The mean values for AUDPC followed the same trend of grade assessment, with highest AUDPC values for the lines BRSMG Talismã, BRS Horizonte, LH-11, CV-46-686, and ESAL Carioca-MG (Table 2). It is worth noting that the AUDPC identifies lines and/or cultivars with higher resistance level, as those classified in the group of resistant lines in both seasons (Pérola, OP-NS-331, MAI-2-5, MAI-18-13, BRSMG Madrepérola, and CV-55). These lines were consistent with the score evaluation, with lower disease severity.

In the separate analysis of variance for grain yield in experiments with and without chemical pathogen control, and for relative yield, significant differences $(p \leq 0.01)$ were stated between the lines in the environment without control in both seasons. In the controlled environment, the differences ( $\mathrm{p} \leq 0.01)$ were only significant in the rainy season 2006/2007. In the dry season, all lines expressed their full yield potential due to the chemical pathogen control. The differences in uncontrolled experiments are due to differences in P. griseola resistance and grain yield of the lines.

In the combined analysis of variance between seasons, in the experiments without chemical control of the pathogen, evaluated in the central and border areas, significant differences $(\mathrm{p} \leq 0.01)$ were observed between seasons, lines and season $x$ line interaction (Table 3 ). In the dry season in 2006 , the average yield was nearly 2.5 times larger than in the rainy season of 2006/2007. This result may be due to excess moisture which is common in the rainy season, causing excessive plant growth and consequently reduced productivity. Because the effect of this vegetative variation is specific to each line, it must have been the main cause of the yield - line interaction, in agreement with the results of Amaro et al. (2007).

There were also significant differences $(p \leq 0.01)$ between lines. The average grain yield of the lines in the two seasons is shown in Table 2. Lines with lowest yield were MA-I-2-5, BRS Horizonte, indicated as susceptible to P. griseola by the grade evaluation, and healthy and diseased leaf area, suggesting that the disease may have been the cause of the yield decrease of these lines. Cultivar BRSM Talismã, which is slightly earlier, may have completed grain filling before the maximum disease severity. The case of LH-11 is the most outstanding, since this cultivar had high disease severity and was one of the highest yielding in both seasons.

In this assessment, the disease set in 55 days after sowing and increased in intensity until the end of the crop cycle. In the initial phase of the disease, which coincided with pod filling, the severity was relatively low. If $P$. griseola occurs later in the cycle, when the plant has reached its full production potential, the pathogen cannot significantly affect the yield of the susceptible lines (Vieira 1983). This may be an explanation for our results. However, if the weather is favorable for the pathogen development and susceptible cultivars are used, yield losses may be significant (Sartorato and Rava 1992, Jesus Júnior et al. 2003, Paula Júnior and Zambolim 2006, Ramalho et al. 2007, Borel et al. 2011).

The yield of the central or border rows of the plots did not differ significantly between evaluations; No interaction involving area was significant, showing a coincident yield behavior of lines evaluated in the central and the border area. This result corroborated the finding of Marques Júnior et al. (1999), that the use of border rows of the experimental plots is unnecessary.

For the relative yield (data not shown), we observed significant differences $(p \leq 0.05)$ in the rainy season 2006/2007; in this case, these differences are due to the variation of lines in terms of pathogen resistance. Therefore, the yield heterogeneity of the lines was increased by the disease occurrence. This fact, coupled with yield differences between the lines, showed that an assessment of grain yield alone is not an appropriate criterion to identify the most resistant lines.

The phenotypic correlations among traits were estimated in each season. In the dry season in 2006, the correlation between the percentage of healthy $(-0.69)$ and diseased leaf area $(0.69)$ was high and significant $(\mathrm{p} \leq 0.05)$ in the second score rating. In the first and third assessment and with AUDPC there was no correlation. In the rainy season $2006 / 2007$, there was a significant correlation $(\mathrm{p} \leq 0.05)$ between the percentage of healthy $(>-0.61)$ and diseased leaf area $(>$ $0.61)$ in the second and third score rating and evaluation with AUDPC. Therefore, the evaluation with scores and AUDPC reflected the areas of healthy and diseased leaves. Correlations with values close to 1 were observed between scores and AUDPC in both seasons, showing consistency in the results of these two assessment procedures.

The estimates of correlations between grain yield and severity grades of angular leaf spot, in the rainy season $2006 / 2007$, were only significant $(\mathrm{p} \leq 0.05)$ in the second score rating (-0.59). For grain yield based on percentage of the healthy and diseased leaf area, the correlation $(\mathrm{p} \leq 0.05)$ was significant ( 0.63 and -0.63 , respectively). The relative yield and other traits were only correlated $(p \leq 0.05)$ with the percentage of healthy and diseased leaf $(0.71$ and -0.71 , respectively). This indicates that the relative yield is the most representative indicator of the damage, similarly to the healthy and diseased leaf are, which are also the best procedures for assessment of disease severity. Unfortunately, the use of this procedure in breeding programs is limited, 
especially in phases in which a large number of treatments are evaluated. The significant correlations of area with score ratings allowed the conclusion that the use of this procedure can be continued without major losses, according to Borel et al. (2011). However, for the evaluation of lines in the process of cultivar recommendation, it is suggested to base the evaluation on area estimates, for a more accurate assessment of the damage caused by the disease. This evaluation also contributes to more precise information for decision making in the recommendation of lines.

\section{ACKNOWLEDGEMENTS}

The authors are indebted to the Research Foundation of the state of Minas Gerais (FAPEMIG) for the financial support and for the $\mathrm{PhD}$ scholarship of the first author.

\section{Eficiência da avaliação da severidade da mancha angular do feijoeiro baseada nas áreas sadia e doente da folha}

Resumo - A severidade da mancha angular do feijoeiro foi avaliada com base nas áreas sadia e doente da folha e na escala diagramática. Foram avaliadas 12 linhagens de feijão nas épocas das secas e das águas. Em cada época foram conduzidos dois experimentos contíguos, com e sem controle químico do patógeno. Foram avaliadas as porcentagens das áreas sadia e doente da folha, severidade da doença segundo uma escala diagramática, área abaixo da curva sob progresso da doença e produtividade de grãos. As áreas sadia e doente da folha são eficientes para avaliar a severidade da mancha angular com uma amostra de 20 a 30 foliolos por parcela. A avaliação de todos os caracteres na área útil ou bordadura da parcela não difere, indicando que a bordadura por parcela é desnecessária. A avaliação da severidade na metade superior da planta discrimina as linhagens mais eficientemente.

Palavras-chaves: Phaseolus vulgaris, Pseudocercospora griseola, área sadia e doente da folha, escala diagramática, severidade da doença.

\section{REFERENCES}

Abreu AFB, Ramalho MAP, Carneiro JES, Peloso MJ, Paula Júnior TJ, Faria LCM, Barros EG, Moreira MA, Pereira Filho IA, Martins M, Santos JB, Rava CA, Costa JGC and Sartorato A (2007) BRSMG Majestoso: another carioca grain type bean cultivar for the state of Minas Gerais. Crop Breeding and Applied Biotechnology 7: 360-366.

Amaro GB, Abreu AFB, Ramalho MAP and Silva FB (2007) Phenotypic recurrent selection in the common bean (Phaseolus vulgaris L.) with carioca-type grains for resistance to the fungi Phaeoisariopsis griseola. Genetics and Molecular Biology 30: 584-588.

Bergamin Filho A, Carneiro SMTPG, Godoy CD, Amorim L, Berger RD and Hau B (1997) Angular leaf spot of phaseolus beans: relationships between disease, healthy leaf area, and yield. Phytopathology 87: 506-515.

Bergamin Filho A, Lopes DB, Amorim L and Godoy CD (1995) Avaliação de danos causados por doenças de plantas. In Luz WC (ed.) Revisão Anual de Patologia de Plantas - RAPP 3: 133-184.

Borel JC, Ramalho MAP, Abreu AFB and Maia LGS (2011) Genetic control of the angular leaf spot reaction in common bean leaves and pods. Scientia Agricola 68: 661-664.

Borém A and Carneiro JES (2006) A cultura. In Vieira C, Paula Jr TJ and Borém A (eds) Feijão. 2a ed., Editora UFV, Viçosa, p. 13-18.

Campbell CL and Madden LV (1990) Introduction to plant disease epidemiology. J Wiley \& Sons, New York, 728p.

Canteri MG, Pria MD, Schiebelbein LM, Silva OC, Amorim L and Bergamin Filho NA (1998) Relações entre área foliar sadia, produtividade, refletância e severidade da mancha angular em feijoeiro. Fitopatologia Brasileira 23: 498-501.
Carneiro JES, Abreu AFB, Ramalho MAP, Paula Junior TJ, Peloso MJ, Melo LC, Pereira HS, Pereira Filho IA, Martins M, Vieira RF, Martins FAD, Coelho MAO, Carneiro PCS, Moreira JAA, Santos JB, Faria LC, Costa JGC and Teixeira H (2012) BRSMG Madrepérola: common bean cultivar with late-darkening Carioca grain. Crop Breeding and Applied Biotechnology 12: 281-283.

Costa JGC, Rava CA, Sartorato A and Purissimo JD (1990) Catálogo de linhagens de feijoeiro comum (Phaseolus vulgaris) do CNPAF: reação às principais doenças e avaliação de características agronômicas. Embrapa-CNPAF, Goiânia, 31p. (Documentos, 32).

Couto MA, Santos JB and Abreu AFB (2005) Selection of Carioca type common bean lines with anthracnose and angular leaf spot- resistance. Crop Breeding and Applied Biotechnology 5: 324-331.

Cruz CD and Castoldi F (1991) Decomposição da interação genótipos x ambientes em partes simples e complexa. Revista Ceres 38: 422-430.

Ferreira DF (2011) Sisvar: a computer statistical analysis system. Ciência e Agrotecnologia 35: 1039-1042.

Ferreira DF (2006) Uso de recursos computacionais. UFLA, Departamento de Ciências Exatas, Lavras, 157p.

Godoy CV, Carneiro S, Iamauti MT, Dallapria M, Amorim L, Berger RD and Bergamin A (1997) Diagrammatic scales for bean diseases: development and validation. Zeitschrift für Pflanzenkrankheiten und Pflanzenschutz 104: 336-345.

Jesus Junior WC, Vale FXR, Coelho RR, Paul PA, Hau B, Bergamin Filho A, Zambolim L and Berger RD (2003) Relationships between angular leaf spot, healthy leaf area, effective leaf area and yield of Phaseolus vulgaris. European Journal of Plant Pathology 109: 625-632.

Hartung K and Piepho HP (2006) Are ordinal rating scales better than 
percent ratings? A statistical and "psychological" review. Euphytica 155: $15-26$.

Marques Júnior OG, Ramalho MAP and Ferreira DF (1999) Emprego do látice no programa de melhoramento do feijoeiro. Ciência e Agrotecnologia 23: 753-759.

Mendonça HA, Santos JB and Ramalho MAP (2003) Genetic control of common bean reaction to Phaeoisriopsis griseola. Crop Breeding and Applied Biotechnology 3: 209-216.

Paranaíba PF, Ferreira DF and Morais AR (2009) Tamanho ótimo de parcelas experimentais: proposição de métodos de estimação. Revista Brasileira de Biometria 27: 255-268.

Paula Júnior TJ and Zambolim L (2006) Doenças. In Vieira, C, Paula Jr. TJ and Borém A(ed.) Feijão. 2a ed., Editora da UFV, Viçosa, p. 359-414

Ramalho MAP, Ferreira DF and Oliveira AC (2012) Experimentação em genética e melhoramento de plantas. $3^{\mathrm{a}}$ ed., EDUFLA, Lavas, 328p.

Sartorato A and Rava CA (1992) Influência da cultivar e do número de inoculações na severidade da mancha angular (Isariopsis griseola) e nas perdas na produção do feijoeiro comum (Phaseolus vulgaris). Fitopatologia Brasileira 17: 247-251.

SAS Institute (2001) SAS/STAT user`s guide. Version 8.1. 2a ed., SAS Institute, Cary.

Silva CA, Abreu AFB and Maia LGS (2012) Chemical composition as related to seed color of common bean. Crop Breeding and Applied Biotechnology 12: 132-137.

Steel RGD, Torrie JH and Dickey DA (1997) Principles and procedures of statistics: a biometrical approach. $3^{\text {a }}$ ed., McGraw-Hill, Nova York, 657p.

Vale FXR, Fernandes Filho EI and Liberato JR (2003) Quant - A software for plant disease severity assessment. In 8th International congress of plant pathology. New Zealand, Christchurch, p.105.

Waggoner PE and Berger RD (1987) Defoliation, disease and growth. Phytopathology 77: 393-398. 